\title{
The crop of desert truffle depends on agroclimatic parameters during two key annual periods
}

\author{
Alberto Andrino $^{1}$ • Alfonso Navarro-Ródenas ${ }^{2} \cdot$ José Eduardo Marqués-Gálvez $^{2,3} \cdot$ Asunción Morte $^{2,3}$ (DD
}

Accepted: 22 September 2019 / Published online: 9 November 2019

(C) INRA and Springer-Verlag France SAS, part of Springer Nature 2019

\begin{abstract}
Desert truffles have become an alternative agricultural crop in semiarid areas of the Iberian Peninsula due to their much appreciated edible value and their low water requirements for cultivation. Although most studies related to desert truffle production point to the sole importance of precipitation, this work is the first systematic study carried out to characterize whether other important agroclimatic parameters, for example reference evapotranspiration, soil water potential, relative air humidity $\%$, aridity index or air vapour pressure deficit, may have an impact on a desert truffle production in an orchard with mycorrhizal plants of Helianthemum almeriense $\times$ Terfezia claveryi for 15 years from the plantation. The results show for the first time that T. claveryi production has two key periods, during its annual cycle: autumn (September to October) and spring (end of March). The aridity index and soil water potential seem to be the most manageable parameters in the field and can be easily controlled by applying irrigation during the abovementioned periods. Agroclimatic parameters can influence the final crop a long time before the desert truffle fruiting season contrary to what happens with other edible mycorrhizal mushrooms. Four different models to manage desert truffle plantations are proposed based on these agroclimatic parameters in order to optimize and stabilize carpophore fructifications over the years.
\end{abstract}

Keywords Terfezia $\cdot$ Helianthemum $\cdot$ Agroclimatic parameters $\cdot$ Precipitation $\cdot$ Aridity index

\section{Introduction}

During the last few decades, great efforts have been made to domesticate diverse species of edible mycorrhizal fungi such as saffron milk caps, matsutake, boletus, black truffles or desert truffles (Hall et al. 2003). However, compared with saprophytic fungi, the cultivation of mycorrhizal fungi continues to be more challenging and fewer species of mycorrhizal fungi are cultivated. One of the main difficulties for their cultivation

Alberto Andrino and Alfonso Navarro-Ródenas contributed equally to this work.

Asunción Morte

amorte@um.es

1 Institute of Soil Science, Leibniz Universität Hannover, 30419 Hanover, Germany

2 Departamento de Biología Vegetal (Botánica), Facultad de Biología, Universidad de Murcia, Campus de Espinardo, 30100 Murcia, Spain

3 Thader Biotechnology SL, Ed. CAID, Campus de Espinardo, 30100 Murcia, Spain is the difficulty involved in the optimization and stabilization of the fruiting bodies crop over time (Morte et al. 2012).

Desert truffles are edible hypogeous fungi of the Pezizaceae family (Pezizales, Ascomycetes), and these mycorrhizal fungi have been used as food for thousands of years in countries with arid or semiarid climates (Volpato et al. 2013). During recent years, these fungal species and their host mycorrhizal plants have become an alternative agricultural crop (Fig. 1 a) in semiarid areas of the Iberian Peninsula due to their much appreciated edible fruiting bodies (Fig. $1 \mathrm{~b}$ ) and their low water requirements for cultivation (Morte et al. 2010, 2012, 2017). The first desert truffle to be cultivated was Terfezia claveryi in symbiosis with Helianthemum almeriense in the south-east of Spain (Honrubia et al. 2001; Morte et al. 2008). T. claveryi fructification usually occurs 2-3 years after plantation, depending on site suitability, season and the framework of plantation, as well as management practices, specially irrigation and weed elimination (Morte et al. 2017). In these plantations, the carpophores fructified yearly and the crop increased with time providing an average of 350-400 kg/ha and year (Morte et al. 2008; 2012; 2017). However, the annual crop is erratic (Morte et al. 2012) and there is a demand for greater knowledge of management techniques 
Fig. 1 a Desert truffle plantation of $H$. almeriense $\times T$. claveryi in the spring of the second year after plantation. b Detail of two fruiting bodies of $T$. claveryi collected in the plantation

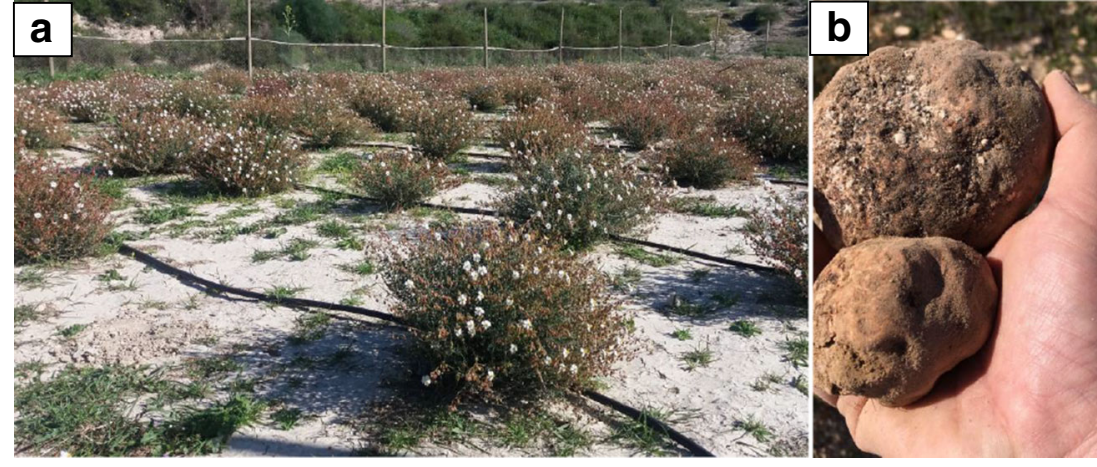

to minimize large interannual fluctuations. For the proper management of $T$. claveryi plantations, it is essential to identify the biotic and abiotic factors that could explain this variability (Navarro-Ródenas et al. 2016).

The host plant $H$. almeriense presents the typical phenology of summer deciduous plants (Flexas et al. 2014) with a maximum of photosynthetic activity during the winter (December to January). This falls gradually as spring (fructification season; February to May) and summer (dehiscence of the leaves) approach (Navarro-Ródenas et al. 2015; MarquésGálvez et al. 2016). This lag time between the plant and fungus phenologies means that there are several moments during the year where environmental conditions could be decisive in their interaction.

Agroclimatic parameters, such as precipitation or temperature, determine the annual crop for other Basidiomycota mycorrhizal fungi before or during the fruiting season (MartínezPeña et al. 2012). However, unlike the fruiting bodies of other Basidiomycota mycorrhizal fungi, which develop in few days (Teramoto et al. 2012; Xu et al. 2016), in the case of Ascomycota such as Tuber and Terfezia, their development is slower and usually takes several months (Olivier et al. 2012; Le Tacon et al. 2014). Therefore, it is expected that long-term environmental factors may influence their development, as has been observed in black truffle (Baragatti et al. 2019).

To date, there is limited knowledge on the environmental factors directly related to desert truffle fructification, with the exception of some suggestions gathered from truffle collectors. In general, truffles appear more frequently during March to April, and according to desert truffle pickers, rain (97.8\%), soil type $(62.2 \%)$ and host plant affect the crop (Mehmet 2017). Around $80 \%$ of the pickers think that winter showers are an important factor that enables the truffle to reach a good size (Mehmet 2017). However, spring showers or spring temperatures were important for $9.1 \%$ and $25 \%$ of the interviewed pickers, respectively (Mehmet 2017). Bradai et al. (2015) found that the natural crop of desert truffle was highly related to the accumulated rainfall from October to December, when the rainfall determines the development of truffles after the dry period (summer) (Mandeel \& Al-Laith 2007; Bradai et al.
2014). Morte et al. (2012) observed a statistical correlation, according to Pearson's test, between the amount of precipitation during autumn (September, October and November) of a given year and the $T$. claveryi truffle crop in spring of the following year. Based on their own experience, Honrubia et al. (2014) recommended that irrigation should be provided at the end of summer/beginning of autumn and, if the dry conditions continue, an extra irrigation of $50-801 / \mathrm{m}^{2}$ at the beginning of the fructification season would greatly improve the crop.

Although most studies related to desert truffle production point to the sole importance of precipitation, a systematic study has never been carried out to characterize whether other important agroclimatic parameters like reference evapotranspiration (ET0), soil water potential, relative air humidity $(\mathrm{RH})$ or air vapour pressure deficit (VPD) may have an impact on the desert truffle harvest, in the same way as occurs in other crops (Ben-Gal et al. 2009). The aim of this study was to determine whether precipitation or any other related agroclimatic parameter can be positively or negatively correlated with dessert truffle productivity in an orchard during 15 years of cultivation and to know the critical periods of the year when those agroclimatic parameters determine the truffle yield. This knowledge is essential to develop management models and establish threshold values of certain parameters, which could help to keep the annual yield of dessert truffle stable over the years in agricultural plantations. Various agroclimatic parameters may vary in intensity, time and duration along a desert truffle crop year, and we hypothesize that there are optimal ranges within which the production of desert truffles is sensitive to precipitation, ET0, soil water potential, VPD, RH and/or related parameters.

\section{Methods}

\subsection{Plantation of Helianthemum almeriense mycorrhized with Terfezia claveryi}

The plantation was located in Zarzadilla de Totana, Lorca, Murcia $\left(37^{\circ} 52^{\prime} 15.5^{\prime \prime} \mathrm{N} 1^{\circ} 42^{\prime} 10.5^{\prime \prime} \mathrm{W}\right)$ at an altitude of 
$870 \mathrm{~m}$ a.s.1. The area belongs to the biogeographic province Castellano-Maestrazgo-Manchega, subsector ManchegoEspuñense, with a warm Mesomediterranean thermotype and semiarid ombrotype with annual precipitation of $289 \pm$ $106 \mathrm{~mm} /$ year (Alcaraz et al. 2008).

In May 1999, the experimental plantation with 60 $H$. almeriense plants mycorrhized with $T$. claveryi was established (Gutiérrez 2001). At the time of planting, the mycorrhized seedlings showed a percentage of mycorrhization higher than $90 \%$ (Gutiérrez 2001). The plantation frame was $0.5 \times 0.5 \mathrm{~m}$ in a total area of $20 \mathrm{~m}^{2}$. To promote the correct establishment of plants, during the first 3 months, mycorrhizal plants were irrigated with $151 / \mathrm{m}^{2}$, every 15 days, until August 1999. In August and January 1999-2000, $501 / \mathrm{m}^{2}$ was supplied at each irrigation time. During the harvest time (March to May), a search for the characteristic soil cracks near the stems of adult $H$. almeriense plants was carried out. During the spring of 2001, the first desert truffles were harvested. After the first fructifications took place, no more artificial irrigation was applied, and the orchard has been allowed to develop with only natural rainfall since then. From 2001 to 2015, all harvested truffles were weighed and the total crop was expressed as fresh weight per hectare (kg/ha) (Fig. 2).

\subsection{Agroclimatic parameters and calculations}

The daily agroclimatic data of dew point, ET0 (FAO), hour below $0{ }^{\circ} \mathrm{C}$, mean temperature, mean relative humidity, precipitation and vapour pressure deficit (VPD) were collected from the nearest meteorological station located in La Paca (Lorca, Spain IMIDA LO41, http://siam.imida.es). In 2010, a MiniMet automatic weather station (Skye Instruments Limited, Wales, UK) was installed close to the plantation and its data were used as a control to check the variations between both stations. The aridity index (AI) was calculated as precipitation divided by ET0, in 10-day periods, according to Barrow (1992).

Soil water potential and soil water potential anomaly were retrieved from the European Drought Observatory (http://edo. jrc.ec.europa.eu) in 10-day periods. Soil water potential from the European Drought Observatory (EDO) is in $\mathrm{pF}$ units, which can easily be converted in $\mathrm{kPa}$ according to the formula: $\mathrm{pF}=\log _{10}-(10 \times \mathrm{kPa})($ Scheffer 2002).

Then, each agroclimatic parameter was recalculated for 10 day periods, providing 36 data per parameter and year. Parameters collected from La Paca agroclimatic station and those from the MiniMet sited in the plantation did not differ substantially during the same time (2010-2015). The period of the year that was associated with each truffle crop datum was considered according to the phenology of truffle fructifications, since no truffles were collected later than June 1, and for this reason, each productive year begins on June 1 of the year before the occurrence of fructification (e.g. truffles produced during 2002 would be associated with agroclimatic data from June 1, 2001 to May 31, 2002).

\subsubsection{Simple moving sum and simple moving average}

Simple moving sum (SMS) and simple moving average (SMA) are calculations applied to time series in order to smooth out short-term fluctuations and highlight longer-term trends or cycles (Johnston et al. 1999). For each agroclimatic parameter, the simple moving average (SMA: dew point, mean temperature, mean relative humidity, soil water potential, soil water potential anomaly and VPD) or the moving sum (SMS: aridity index, ET0, hours below $0{ }^{\circ} \mathrm{C}$ and precipitation) was calculated for periods of 10, 20, 30, 40, 50, 60 and 70 days, turning the initial data set of 36 values into 252 values per parameter and year.

\subsubsection{Pearson correlation analysis and heatmap}

To infer which meteorological parameters had an effect on desert truffle crop, Pearson correlation tests $(P>0.05)$ were carried out between the SMA and SMS of the different parameters and the annual truffle yield $(\mathrm{kg} / \mathrm{ha})$. Therefore, for each parameter, 7 different sets of Pearson correlations were calculated between the SMA or SMS values, as appropriate, and the truffle yield values. Finally, the set of SMA or SMS data, which showed the highest number of significant correlations with desert the truffle crop, was selected. By using this rule, whereby the greatest numbers of significant correlations are selected, it is possible to realize which period of the year is relevant for a given parameter, for the desert truffle crop. The optimal values of SMS and SMA of agroclimatic parameters which presented some correlation with the desert truffle crop were then represented in a heatmap (Fig. 3), where the optimal periods of each parameter were grouped depending on whether they correlated positively or negatively with desert truffle crop.

\subsubsection{Agroclimatic parameter comparison}

To find out the trend in desert truffle crop along the 15 years of this study, the cumulative average was calculated. This value was then used to establish two groups, defined by low productive $(L)$ or high productive $(H)$ years, compared with the accumulated mean for the period 2000-2015. Two groups, $L$ and $H$, were produced for the optimal SMS and SMA values of each meteorological parameter. The values of each group, $L$ and $H$, were compared (the Mann-Whitney $\mathrm{U}$ test) to identify which periods of the year showed significant differences for each meteorological parameter. 


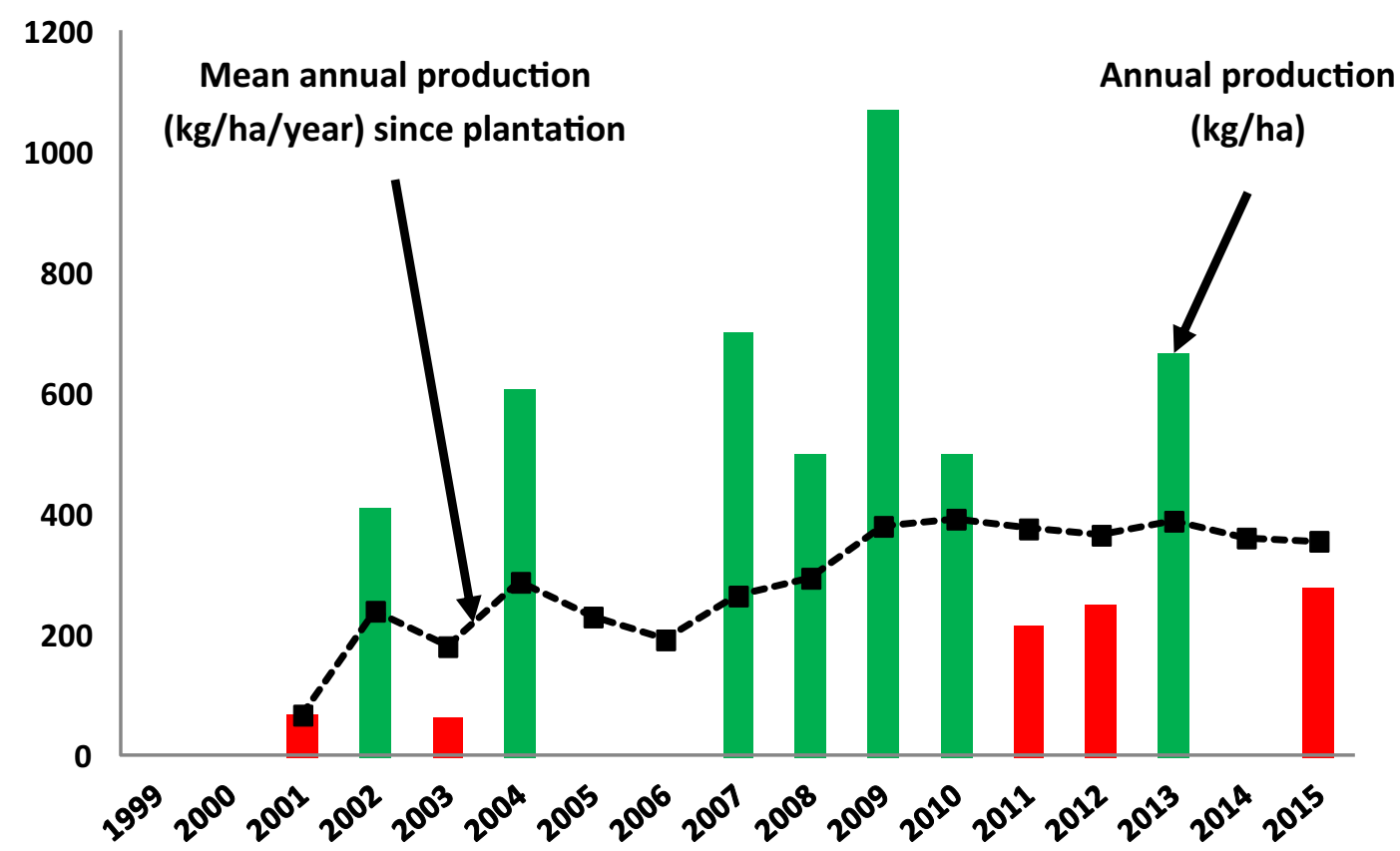

Fig. 2 Variation of the interannual desert truffle crop ( $\mathrm{kg} / \mathrm{ha}$ on a total area of $20 \mathrm{~m}^{2}$ ) from 2001 to 2015 . Dashed line represents the mean annual crop $\left(\mathrm{kg} / \mathrm{ha} /\right.$ year on a total area of $\left.20 \mathrm{~m}^{2}\right)$ since plantation. Bars represent the total annual crop of ascocarps per year. Red bars are the years when the yields fell below the annual mean $\left(\mathrm{kg} / \mathrm{ha} /\right.$ year on a total area of $\left.20 \mathrm{~m}^{2}\right)$

\subsubsection{Classification and regression trees}

Classification and regression tree (C\&RT) is a nonparametric and nonlinear method that determines, via tree-building algorithms, a set of if-then logical (split) conditions that allow the accurate prediction or classification of cases. C\&RT are methods that deliver models that meet both explanatory and predictive goals. Two of the strengths of this method are the and are classified as low crop years $(L)$. Green bars are those when the yields were above the annual mean $\left(\mathrm{kg} / \mathrm{ha} /\right.$ year on a total area of $\left.20 \mathrm{~m}^{2}\right)$ and classified as high crop years $(H)$. There are no bars when the crop was zero (2014) or less than $2 \mathrm{~kg} / \mathrm{ha}$ on a total area of $20 \mathrm{~m}^{2}(2005,2006)$

simple graphical representation by trees and the compact format of the natural language rules (Breiman \& Ihaka 1984). C\&RT were calculated to predict the optimal SMA and SMS values of each meteorological parameter with an impact on the desert truffle crop. For every newly created sub-node, a minimum size for a son node of $n=3$ cases was used as stop criteria. Then, the values predicted by the regression tree were evaluated by computing the root mean square error (RMSE)

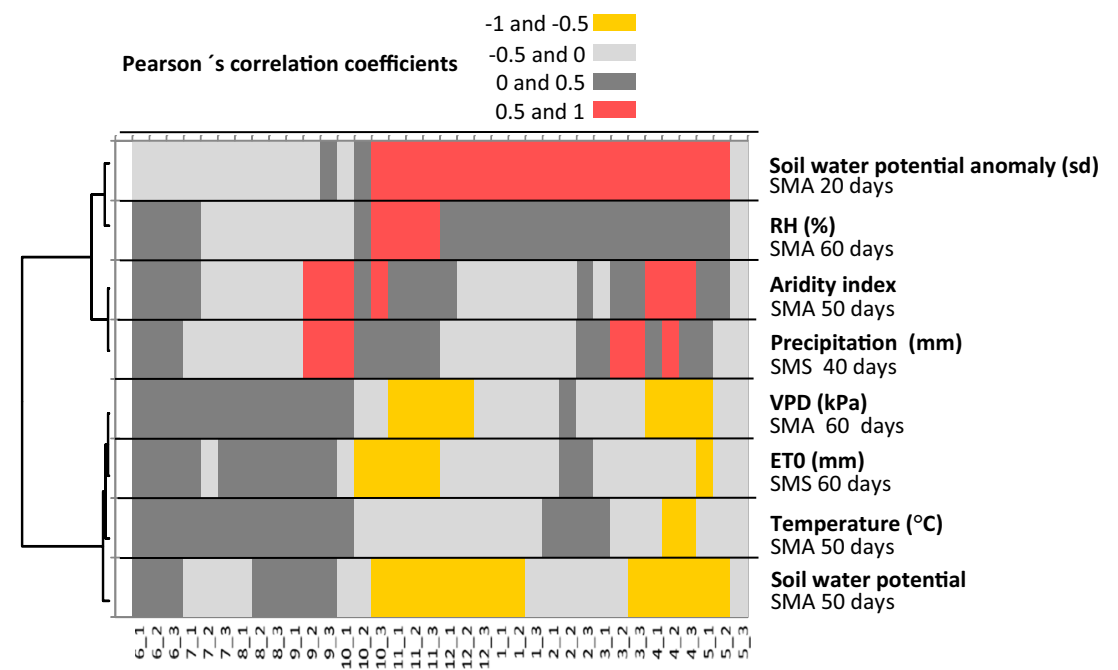

Fig. 3 Heatmap grouping the significantly $(P<0.05)$ positive (red) and negative (yellow) Pearson's correlations among the agroclimatic parameters and the truffle crop in ten day periods. The dark and light grey bars indicate no statistically significant Pearson correlations. The average (SMA) or cumulative (SMS) period (days) used to calculate the
Pearson correlations are given under the name of each meteorological parameter. The SMA or SMS period is that showing the highest number of significant correlations. On the abscissa axis: periods of the year are represented by month numbers and each month is divided into sub-periods of 10 days 

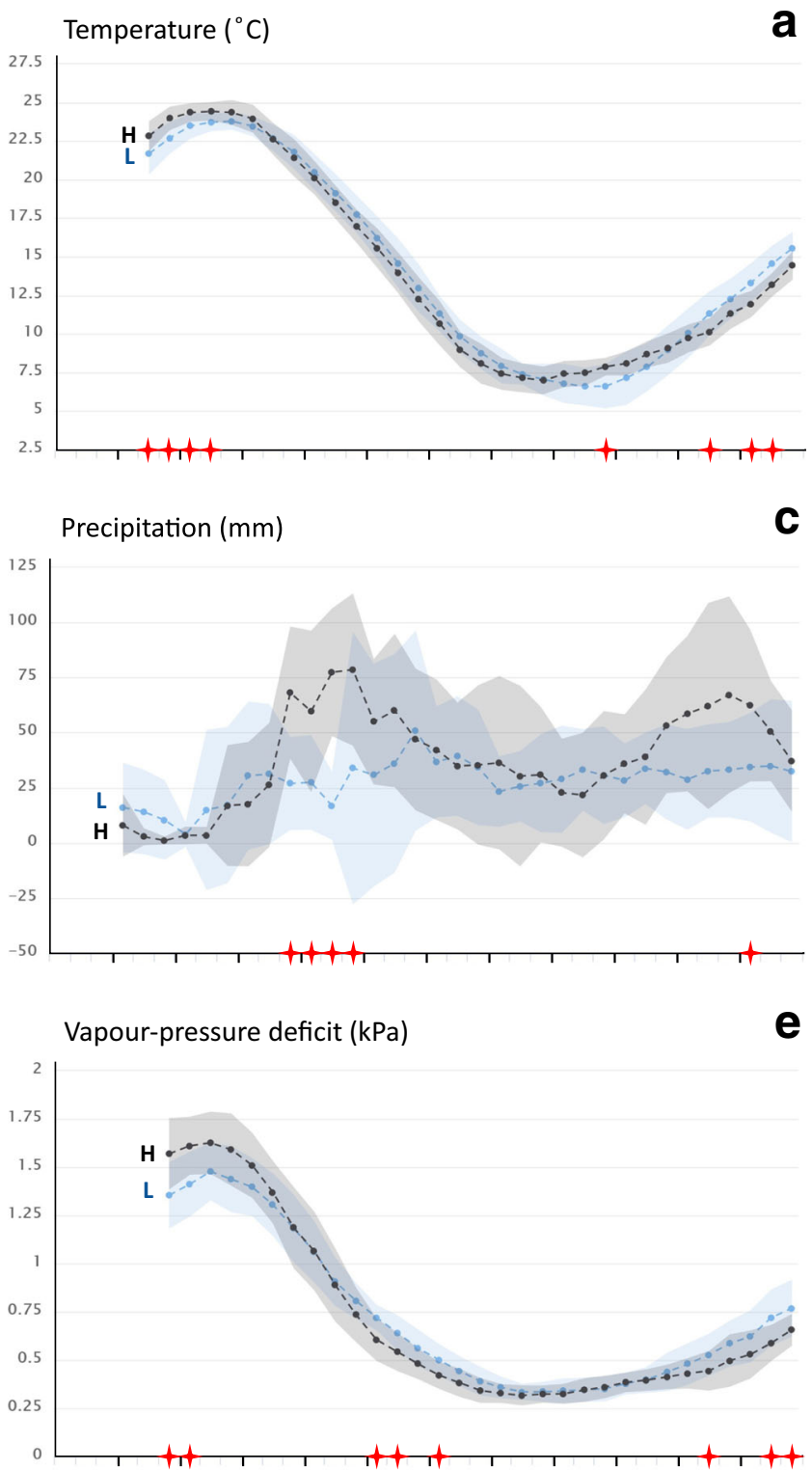

\section{Soil water potential $(\mathrm{pF})$}

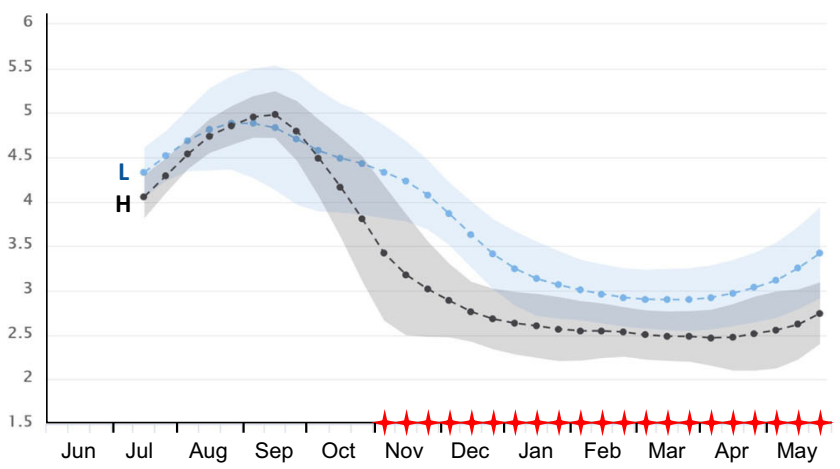

Fig. 4 Annual agroclimatic parameter profile showing the mean value (dashed line with circles) and standard deviation (coloured shadow) of the different agroclimatic parameters represented for high productive years ( $H$, black colour) and low productive years ( $L$, blue colour). The plotting of the different parameters starts at different dates due to the different

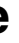

g
Relative humidity (\%)

b

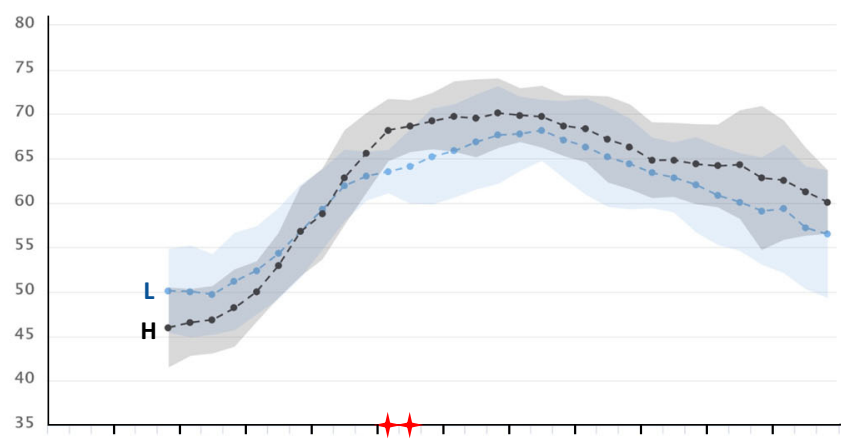

Evapotranspiration ( $\mathrm{mm}$ )

d

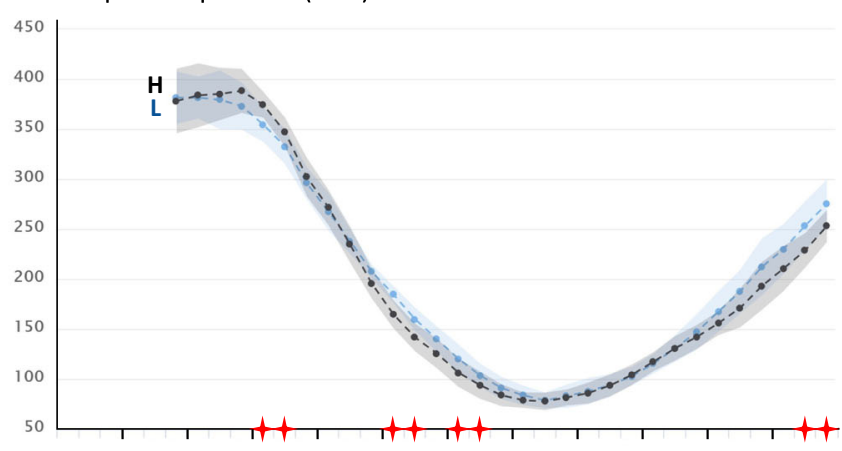

Aridity index

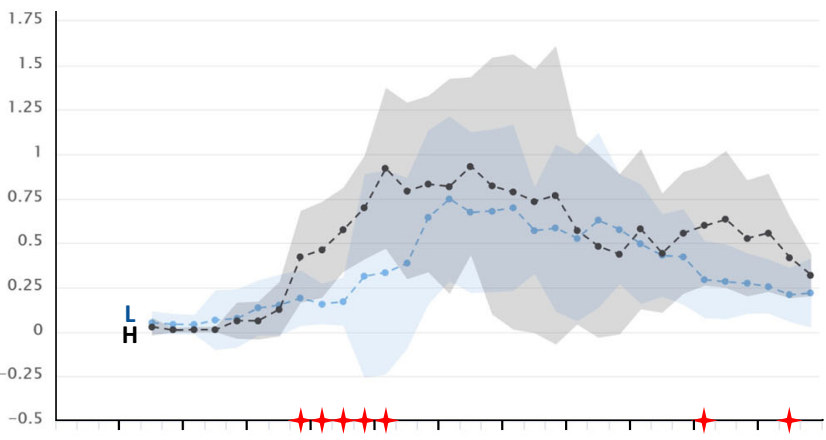

Soil water potential anomaly (sd)

h

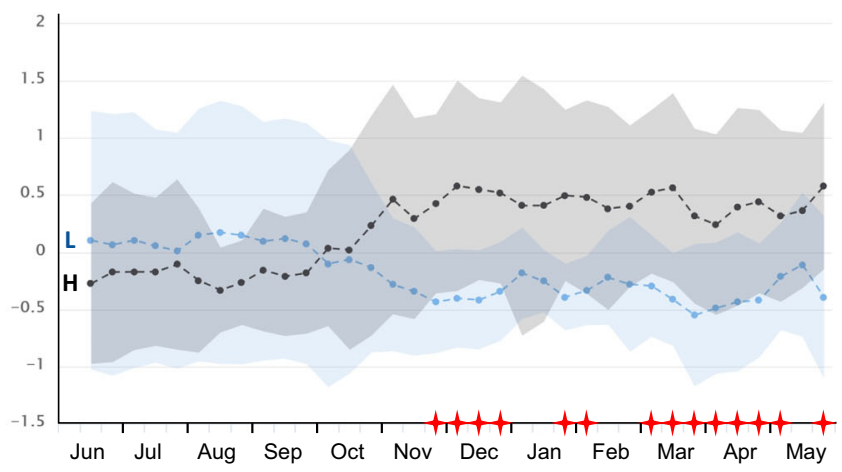

SMA or SMS calculated for each one. The axis of abscissa shows the months of the year distributed in periods of 10 days and the significantly different values between $L$ and $H$ productions are marked with a red star where it corresponds, as a result of the Mann-Whitney $U$ test $(P<0.1)$ 

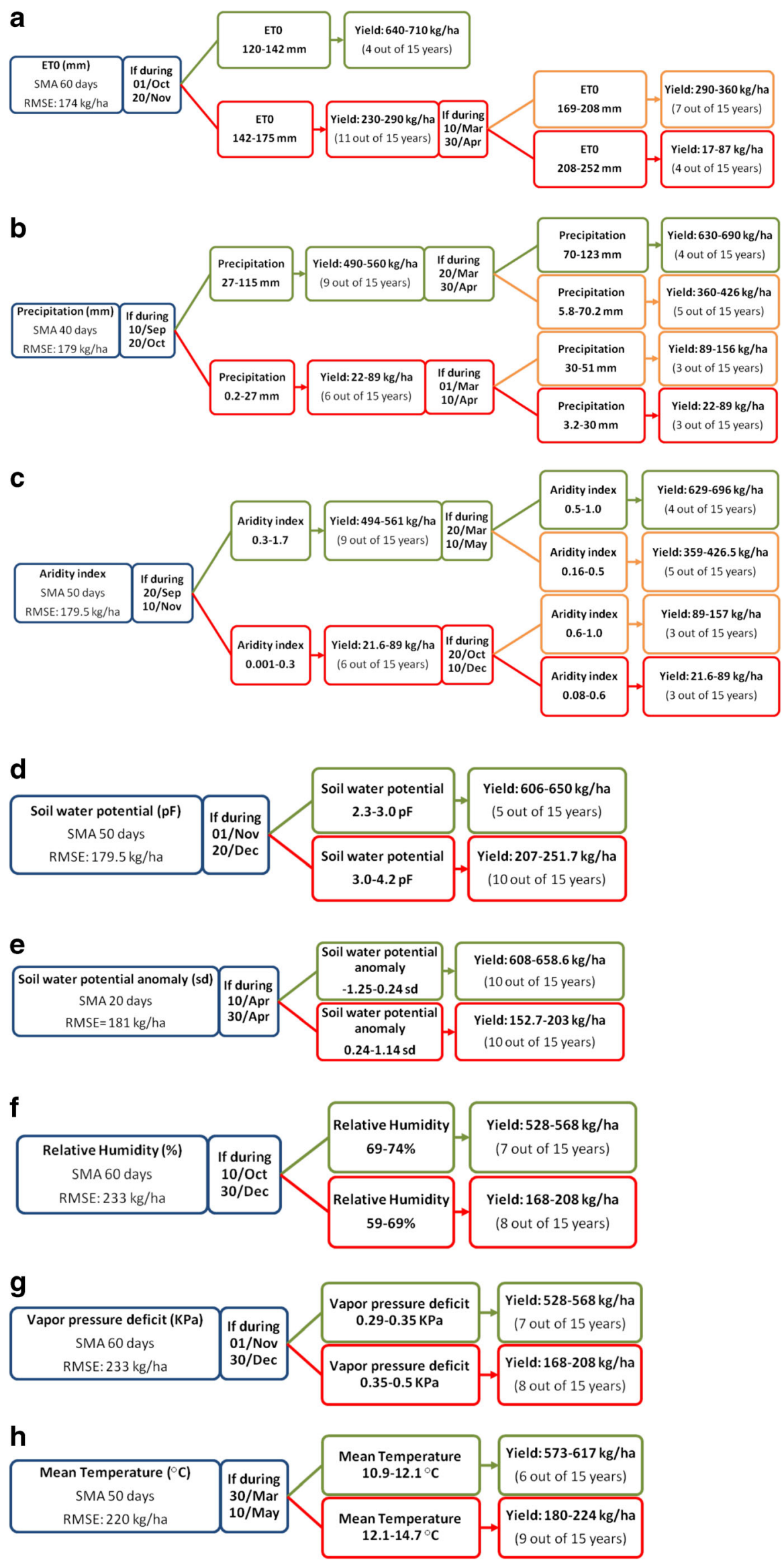
Fig. 5 Classification and regression tree analysis of the different agroclimatic parameters. The first box on the left (blue) shows the optimal SMA or SMS values derived from the heatmap (Fig. 3) and used to calculate the C\&RT. The same box includes the RMSE value calculated between the observed and the predicted truffle crop. The following box to the right shows the dates predicted by the C\&RT with the higher impact on the truffle crop. The two nodes on the right show the range of the predicted values of the different agroclimatic parameters, the desert truffle crop ranges and the number of years included in each son node. Green nodes show the optimal scenario, orange nodes show the suboptimal scenarios and red nodes show the undesirable scenario. a ET0. b Precipitation. c Aridity index. d Soil water potential. e Soil water potential anomaly. f Relative humidity. $\mathbf{g}$ Vapour pressure deficit. h Mean temperature

between the observed desert truffle crop and the predicted values. RMSE quantifies how different sets of values are, whereby the smaller the RMSE value $(\mathrm{kg} / \mathrm{ha})$, the closer the predicted and observed values.

\subsection{Software packages}

Descriptive statistics, Pearson correlations, heatmap and the Mann-Whitney U test were calculated with XLSTAT 2018 (Addinsoft 2018). The $L$ and $H$ agroclimatic parameter comparison graphs were created with Rapidminer v 9.3.

\section{Results and discussion}

\subsection{Desert truffle crop}

Once the plantation was established, it took 2 years before the first $T$. claveryi fruiting event occurred, during the spring of 2001. In the following years, the plantation increased its mean annual crop size almost linearly until 2009 (Fig. 2), when it reached a cumulative average crop of $379 \mathrm{~kg} / \mathrm{ha}$ on a total area of $20 \mathrm{~m}^{2}$ and remained almost constant with standard deviation of $\pm 14 \mathrm{~kg} / \mathrm{ha}$ throughout the rest of years. The average desert truffle crop was $355 \mathrm{~kg} / \mathrm{ha} /$ year over the 15 years on a total area of $20 \mathrm{~m}^{2}$. The stability of the accumulated crop average indicates that, over 10 years of sampling, the accumulated average fluctuated less than $4 \%$ and, therefore, we could consider that the minimum sample size was adequate. However, the yearly crop showed large interannual fluctuations with a standard deviation of $\pm 318 \mathrm{~kg} /$ ha (Fig. 2). After the first fructification, two years following plantation (2001), the crop was zero (2014) or less than $2 \mathrm{~kg}$ /ha on a total area of $20 \mathrm{~m}^{2}(2005,2006)$ in only 3 years. The greatest harvest was 2009 with $1069 \mathrm{~kg} / \mathrm{ha}$ on a total area of $20 \mathrm{~m}^{2}$. Despite the high standard deviation, according to a Grubbs' test, no value should be considered as an outlier (Grubbs 1950).

\subsection{Phenology and seasonal influence of agroclimatic parameters}

As we hypothesized, our results point to a seasonal influence of the different agroclimatic parameters on the crop of T. claveryi desert truffles. Eight out of ten parameters (aridity index, ET0, mean temperature, mean relative humidity, precipitation, soil water potential, soil water potential anomaly and VPD) showed significant Pearson's correlations with the T. claveryi crop size. The start of the desert truffle year can be taken as June 1. During summer (June to August), $H$. almeriense plants remain vegetative and photosynthetically inactive and mycorrhizal structures are almost undetectable (Morte et al. 2010; Navarro-Ródenas et al. 2015). According to the heatmap (Fig. 3), annual profiles (Fig. 4) and C\&RTs (Fig. 5), this time seems to be unimportant for the future truffle crop since no significant correlations were observed and only temperature and VPD showed significant but slight changes (Fig. 4 c, a), whereby the stressful condition seems to favour the desert truffle yield. $H$. almeriense is a summer deciduous plant but if the conditions are not sufficiently dry, the plant does not lose its leaves, which could eventually result in plant death (Morte et al. 2010). Therefore, in general, climatic parameters, particularly drought conditions in summer, are not critical for desert truffle, contrary to what happens in other close species such as black truffle (Le Tacon et al. 1982, 2014; Büntgen et al. 2012, 2019; Baragatti et al. 2019). This could be due to the different fruiting seasons and to the difference in the phenology of the host plants, since $H$. almeriense is a summer deciduous plant, while Quercus species are perennial or winter deciduous plants.

Autumn (September, October and November) seems to be a key season for the final truffle crop. All agroclimatic parameters, with the exception of temperature, showed significantly correlations with truffle crop (Fig. 3). According to the heatmap (Fig. 3), RH, precipitation and AI are the parameters most strongly related to yield (Fig. 3). Precipitation and AI show statistically significant different annual profiles during autumn (Fig. 4 c, f). In this season, a window of approximately 40 days (from September 20 to October 31) occurs, during which accumulated rainfall of around $801 / \mathrm{m}^{2}$ would give rise to an $H$ year (Fig. 4 c). However, if the accumulated rainfall in this window is below $271 / \mathrm{m}^{2}$, this year's crop would be severely affected and values lower than $89 \mathrm{~kg} / \mathrm{ha}$ are to be expected (Fig. 5 b). Anyway, the final effectiveness of the rain during autumn may be affected by other parameters such as ET0 (Fig. 3), making the water available for plants by more or less elapsed time. As a combination of these two parameters, the AI was calculated and was found to be the agroclimatic parameter with the most significant differences (5) during autumn between $H$ and $L$ years (Fig. 4 f). The high dependence of agroclimatic parameters away in time corroborates the hypothesis regarding the early formation of truffle primordia in 
Table 1 Management proposal based on the aridity index (AI) threshold. This table represents the ET0 and precipitation averages of the three lowest production years and the irrigation proposed

\begin{tabular}{|c|c|c|c|c|c|c|}
\hline Periods & ET0 (mm) & Precipitation (mm) & AI & AI threshold & Required water* (mm) & Irrigation** $(\mathrm{mm})$ \\
\hline September 21-30 & 36.7 & 1.2 & 0.033 & 0.35 & 12.85 & 11.65 \\
\hline October $1-10$ & 31.1 & 2.2 & 0.0708 & 0.35 & 10.89 & 8.60 \\
\hline October 11-20 & 28.8 & 1.5 & 0.0503 & 0.35 & 10.08 & 8.58 \\
\hline October $21-31$ & 29.5 & 2.0 & 0.0662 & 0.35 & 10.33 & 8.33 \\
\hline November $1-10$ & 22.3 & 1.2 & 0.0538 & 0.35 & 7.81 & 6.61 \\
\hline March 21-31 & 31.2 & 7.0 & 0.2238 & 0.50 & 15.60 & 8.6 \\
\hline April 1-10 & 35.4 & 4.3 & 0.1223 & 0.50 & 17.70 & 13.40 \\
\hline April 11-20 & 33.8 & 6.7 & 0.1969 & 0.50 & 16.90 & 10.2 \\
\hline April 21-30 & 48.1 & 9.5 & 0.1963 & 0.50 & 24.05 & 15.05 \\
\hline May $1-10$ & 34.1 & 11.9 & 0.3496 & 0.50 & 17.05 & 5.15 \\
\hline Total & & 47.5 & & & 143.26 & 96.17 \\
\hline
\end{tabular}

$* \mathrm{RW}_{p}=\mathrm{AI}_{t} \times \mathrm{ET}_{p}$

$* * I_{\mathrm{p}}=\mathrm{RW}_{\mathrm{p}}-P_{\mathrm{p}}$

$R W$ the required water, $A I_{t}$ the aridity index threshold, $E T O_{p}$ the evapotranspiration during the period, $I_{p}$ the irrigation during the periods, $P_{p}$ the precipitation during the periods

autumn (Pacioni et al. 2014; Bordallo 2007). Moreover, the correlation with soil water potential, the longest correlation between the crop and any other agroclimatic parameters (Fig. 3), is also evident at the end of autumn (Fig. 4 g).

During winter (December, January, February), the host plant $H$. almeriense presents the maximum gas exchange activity and amount of mycorrhizal roots (Marqués-Gálvez et al. 2016), but few and only weakly significant correlations with the studied parameters were found (Fig. 3). Only in the case of temperature, between 11 th of January to 31 st of February, was it possible to detect significant differences between $H$ and $L$ years (Fig. 4 a), although this difference was less than $1{ }^{\circ} \mathrm{C}$. Soil water potential was the parameter which showed most correlations with truffle crop throughout this season (Fig. 3). Morte et al. (2010) and Navarro-Ródenas et al. (2013) noted a decrease in gas exchange parameters in drought conditions, whereby a high soil water potential could facilitate the production of photoassimilates that might be derived later towards the formation of truffles.

Spring (March, April, May) is when T. claveryi usually fructifies, although the beginning of the fruiting period can differ widely from one year to another. As expected, several agroclimatic parameters showed significant correlations with the final production of truffles. However, they were fewer in number and lower in intensity than in the other seasons further from the time of fruiting (Fig. 3). Spring rainfall, ET0 and AI appear to be important and significantly different profiles were observed between $H$ and $L$ years (Fig. 4). In fact, spring precipitation could complement autumn rainfalls when sufficient and partially correct the yield if the rainfalls had not being

Table 2 Management proposal based on the aridity index (AI) threshold. This table represents the ET0 and precipitation averages of the three highest production years and the irrigation proposed

\begin{tabular}{|c|c|c|c|c|c|c|}
\hline Periods & ET0 & Precipitation & AI & AI threshold & Required water & Irrigation \\
\hline September 21-30 & 31.7 & 47.3 & 1.4936 & 0.35 & 11.09 & - \\
\hline October $1-10$ & 32.0 & 8.0 & 0.2504 & 0.35 & 11.2 & 3.2 \\
\hline October 11-20 & 24.1 & 16.5 & 0.6872 & 0.35 & 8.44 & - \\
\hline October 21-31 & 21.2 & 19.5 & 0.8968 & 0.35 & 7.35 & - \\
\hline November 01-10 & 13.7 & 28.2 & 2.0574 & 0.35 & 4.79 & - \\
\hline March 21-31 & 33.1 & 34.0 & 1.0268 & 0.50 & 16.55 & - \\
\hline April 1-10 & 35.5 & 13.9 & 0.3932 & 0.50 & 17.75 & 3.85 \\
\hline April 11-20 & 40.7 & 21.8 & 0.5361 & 0.50 & 20.35 & - \\
\hline April 21-30 & 45.4 & 18.9 & 0.4166 & 0.50 & 22.70 & 3.8 \\
\hline May 1-10 & 52.0 & 5.8 & 0.1110 & 0.50 & 26 & 20.2 \\
\hline Total & & 213.9 & & & 146.22 & 31.05 \\
\hline
\end{tabular}


sufficiently abundant (Fig. 5). During spring, photosynthesis decreases progressively as the plants approach to summer (Navarro-Ródenas et al. 2015). This reduction in host plant photosynthesis may be the factor that triggers the fruiting of T. claveryi. As Pacioni et al. (2014) pointed out, most changes that stimulate fruiting body formation negatively affect mycelial growth, and therefore, less favourable conditions for mycelial growth would favour the formation of fruiting bodies. Another group of related agroclimatic parameters in spring comprises temperature and VPD, which are negatively correlated with the desert truffle yield. It seems that mild temperatures and, consequently, mild VPD could increase the desert truffle yield. Some authors have previously reported a decrease in photosynthesis if the atmospheric demand (VPD) reaches certain values and further the senescence and fall of leaves, so high values of VPD during the fruiting stage could cause a premature end of the fruiting period with the consequent fall in yield (Morte et al. 2010; León-Sánchez et al. 2016; Marqués-Gálvez et al. 2016). The third and the most clearly correlated agroclimatic parameter with the desert truffle yield was soil water potential. Indeed, this parameter showed a close correlation from the end of autumn, during winter and to the end of spring. T. claveryi mycelial growth is improved by moderate drought stress (Navarro-Ródenas et al. 2012) but, like other hipogeous ascocarps, fruit bodies also develop over a period of months and developing truffles are susceptible to desiccation. Thereafter, adequate soil water potential needs to be maintained throughout the harvest season (Bruhn \& Hall 2011) so that the introduction of soil water potential sensors in future desert truffle plantations could help in their management.

\subsection{Management proposal}

As a summary, we propose four different models to manage desert truffle plantations of $T$. claveryi in $H$. almeriense plants in a semiarid Mediterranean climate, depending on the resources and facilities available in the plantations:

1) Based on the aridity index and decision tree (Fig. 5 c): The ET0 should be monitored during the 50 days before November 10 and irrigation applied in order to maintain the aridity index at least over a threshold of 0.35 (Tables 1 and 2) and during the 50 days before May 10 at least over the threshold of 0.50 (Tables 1 and 2). ET0 and precipitation values can be obtained from a weather station sited in the plantation or from the closest official meteorological station.

2) Based on soil water potential and annual profile (Fig. 4 g): Irrigation should be carefully controlled from 10 November in order to maintain the soil water potential $(\mathrm{pF})$ always below the average value of $L$ years and as close as possible to the average value of $H$ years according to the values in Fig. $4 \mathrm{~g}$. The $\mathrm{pF}$ values should be measured by using field probes like MPS-2 or MPS- 6 Dielectric Water Potential Sensors (Decagon Devices, Inc. Pullman WA) or similar probes, which are able to register the data range observed in our study.

3) Based on a combination of aridity index and soil water potential: The irrigation should be monitored and applied during autumn ( 50 days before 10 November) in order to maintain the aridity index over the threshold and, from November, bearing in mind soil water potential that should not be allowed to surpass those of $L$ year values. In spring (50 days before 10 May), the irrigation should be decided on the basis of aridity index or soil water potential and irrigation should only be applied when either of these two parameters reaches its critical value.

4) Based on soil water potential anomaly and annual profiles (Fig. 4 h): The irrigation should be monitored from November 10 in order to maintain the soil water potential anomaly always below the average value of $L$ years and as close as possible to the average value of $H$ years according to the values in Fig. $4 \mathrm{~h}$. The soil water potential anomaly values can be checked in the European Drought Observatory website (EDO, http://edo.jrc.ec. europa.eu).

All these models should be adjusted carefully to each site of cultivation, taking into account other environmental factors that could modulate the final result, such as type of soil, slope, altitude and orientation.

\section{Conclusions}

Our results show for the first time that annual $T$. claveryi crop yields are mainly affected by agroclimatic parameters during the autumn and spring months in a semiarid climate. Moreover, the aridity index and soil water potential are the agroclimatic parameters which mostly determine the annual desert truffle crop. The agroclimatic parameters play a role a long time before the desert truffle fruiting season contrary to what happens with other edible mycorrhizal mushrooms. The key agroclimatic parameters can be controlled by applying irrigation in the field, at the identified times in autumn and spring, and so allow the desert truffle crop to be maximized.

Acknowledgements Authors are grateful to Dr. Janusz Zwiazek for useful comments on the manuscript, to Dr. Frank Schaarschmidt and Dr. Antonio Maurandi's team for their help and advice in carrying out the statistical analyses, and to Francisco González for providing the crop data of his desert truffle plantation.

Funding information The authors received financial support from AEI/ FEDER, UE (CGL2016-78946-R) and Fundación Séneca-Agencia de 
Ciencia y Tecnología de la Región de Murcia (20866/PI/18). ANR is a recipient of a postdoctoral contract (IJCI-2016-28252) from the Ministerio de Economía y Competitividad (MINECO). JEMG is a recipient of a PhD grant (DI-14-06904) from the Ministerio de Economía y Competitividad (MINECO).

\section{Compliance with ethical standards}

Conflict of interest The authors declare that they have no conflict of interest.

\section{References}

Addinsoft (2018) XLSTAT. Extensión de análisis estadístico para Microsoft Excel

Alcaraz F, Barreña J, Clemente M, González-Garnés J, Rivera D, Ríos S (2008) Manual de interpretación de los hábitats naturales y seminaturales de la Región de Murcia. Tomo 1: hábitats y sistemas de hábitats. Murcia: Dirección General del Medio Natural, Consejería de Desarrollo Sostenible y Ordenación del Territorio, Región de Murcia

Ben-Gal A, Agam N, Alchanatis V, Cohen Y, Yermiyahu U, Zipori I et al (2009) Evaluating water stress in irrigated olives: correlation of soil water status, tree water status, and thermal imagery. Irrig Sci 27: 367-376. https://doi.org/10.1007/s00271-009-0150-7

Baragatti1 M, Grollemund PM, Montpied P, Dupouey JL, Gravier J, Murat C, Le Tacon F (2019) Influence of annual climatic variations, climate changes, and sociological factors on the production of the Périgord black truffle (Tuber melanosporum Vittad.) from 19031904 to 1988-1989 in the Vaucluse (France). Mycorrhiza 29:113125. https://doi.org/10.1007/s00572-018-0877-1

Barrow CJ (1992) World atlas of desertification (United nations environment programme), edited by N. Middleton and D.S.G. Thomas, Edward Arnold, London. isbn:0-340-55512-2

Bordallo JJ (2007) Estudio del ciclo biológico de Terfezia claveryi Chatin. Memoria de Suficiencia Investigadora del Programa de Doctorado de Biología Vegetal. Universidad de Murcia, Spain

Bradai L, Bissati S, Chenchouni H (2014) Desert truffles of the North Algerian Sahara: diversity and bioecology. Emir J Food Agric 26(5): 425-435. https://doi.org/10.9755/ejfa.v26i5.16520

Bradai L, Bissati S, Chenchouni H, Amrani K (2015) Effects of climate on the productivity of desert truffles beneath hyper-arid conditions. Int J Biometeorol 59(7):907-915. https://doi.org/10.1007/s00484014-0891-8

Breiman L, Ihaka R (1984) Nonlinear discriminant analysis via scaling and ACE: Department of Statistics. University of, California

Bruhn J, Hall M (2011) Burgundy black truffle cultivation in an agroforestry practice. Agrofor Action, Conference Proceedings

Büntgen U, Egli S, Camarero JJ, Fischer EM, Stobbe U, Kauserud H, Tegel W, Sproll L, Stenseth NC (2012) Drought-induced decline in Mediterranean truffle harvest. Nat Clim Chang 2(12):827-829. https://doi.org/10.1038/nclimate1733

Büntgen U, Oliach D, Martínez-Peña F, Latorre J, Egli S, Krusic PJ (2019) Black truffle winter production depends on Mediterranean summer precipitation. Environ Res Lett 14(7):074004. https://doi. org/10.1088/1748-9326/ab1880

Flexas J, Diaz-Espejo A, Gago J, Gallé A, Galmés J, Gulías J, Medrano H (2014) Photosynthetic limitations in Mediterranean plants: a review. Environ Exp Bot 103:12-23. https://doi.org/10.1016/j.envexpbot. 2013.09.002

Grubbs FE (1950) Sample criteria for testing outlying observations. Ann Math Stat 21(1):27-58
Gutiérrez A (2001) Caracterización, Micorrización y Cultivo en Campo de las Trufas del Desierto. University of Murcia, Murcia, Spain, Dissertation

Hall IR, Yun W, Amicucci A (2003) Cultivation of edible ectomycorrhizal mushrooms. Trends Biotechnol 21(10):433-438. https://doi.org/10.1016/S0167-7799(03)00204-X

Honrubia M, Gutiérrez A, Morte A (2001) Desert truffle plantation from southeast Spain. In: Edible Mycorrhizal Mushrooms and Their Cultivation: Proceedings of the Second International Workshop on Edible Mycorrhizal Mushrooms. Christchurch, New Zealand pp 3-5

Honrubia M, Andrino A, Morte A (2014) Preparation and maintenance of both man-planted and wild plots. In: Kagan-Zur V, Roth-Bejerano N, Sitrit Y, Morte A eds. Desert truffles: phylogeny, physiology, distribution and domestication. Berlin, Heidelberg: Springer Berlin Heidelberg, pp. 367-387

Johnston FR, Boyland JE, Meadows M, Shale E (1999) Some properties of a simple moving average when applied to forecasting a time series. J Oper Res Soc 50(12):1267-1271. https://doi.org/10.1057/ palgrave.jors. 2600823

Le Tacon F, Delmas J, Gleyze R, Bouchard D (1982) Effect of soil water regime and fertilization on fructification of the black truffle of Perigord (Tuber melanosporum Vitt.) in south east of France. Acta Oecol, Oecol Appl 3(4):291-306

Le Tacon F, Marçais B, Courvoisier M, Murat C, Montpied P, Becker M (2014) Climatic variations explain annual fluctuations in French 'Périgord black truffle' wholesale markets but do not explain the decrease in 'black truffle' production over the last 48 years. Mycorrhiza 24(1):115-125. https://doi.org/10.1007/s00572-0140568-5

León-Sánchez L, Nicolás E, Nortes PA, Maestre FT, Querejeta JI (2016) Photosynthesis and growth reduction with warming are driven by nonstomatal limitations in a Mediterranean semi-arid shrub. Ecol Evol 6(9):2725-2738. https://doi.org/10.1002/ece3.2074

Mandeel QA, Al-Laith AAA (2007) Ethnomycological aspects of the desert truffle among native Bahraini and non-Bahraini peoples of the Kingdom of Bahrain. J Ethnopharmacol 110(1):118-129. https://doi.org/10.1016/j.jep.2006.09.014

Martínez-Peña F, de-Miguel S, Pukkala T, Bonet JA, Ortega-Martínez P, Aldea J, Martínez de Aragón J (2012) Yield models for ectomycorrhizal mushrooms in Pinus sylvestris forests with special focus on Boletus edulis and Lactarius group deliciosus. For Ecol Manage 282:63-69. https://doi.org/10.1016/j.foreco.2012.06.034

Marqués-Gálvez J, Navarro-Ródenas A, Nicolás E, Morte A (2016) Combined effect of vapour pressure deficit and irrigation on desert truffle mycorrhizal plants. VIII International Workshop on Edible Mycorrhizal Mushroom, Cahors (France)

Mehmet A (2017) Ethnomycological aspects of traditional usage and indigenous knowledge about the arid-semi arid truffles consumed by the residents of the eastern anatolia region of Turkey. Gazi Univ $\mathbf{J}$ Sci 30(4):57-70

Morte A, Andrino A, Honrubia M, Navarro-Ródenas A (2012) Terfezia cultivation in arid and semiarid soils. In: Zambonelli A, Bonito GM eds. Edible Ectomycorrhizal Mushrooms: Current Knowledge and Future Prospects. Berlin, Heidelberg: Springer Berlin Heidelberg, pp. 241-263. https://doi.org/10.1007/978-3-642-33823-6_14

Morte A, Honrubia M, Gutiérrez A (2008) Biotechnology and cultivation of desert truffles. In: Varma A, ed. Mycorrhiza 3rd Edition. Springer Berlin Heidelberg pp. 467-483. https://doi.org/10.1007/978-3-54078826-3 23

Morte A, Navarro-Ródenas A, Nicolás E (2010) Physiological parameters of desert truffle mycorrhizal Helianthemun almeriense plants cultivated in orchards under water deficit conditions. Symbiosis. 52(2-3):133-139. https://doi.org/10.1007/s13199-010-0080-4

Morte A, Pérez-Gilabert M, Gutiérrez A, Arenas F, Marqués-Gálvez JE, Bordallo JJ, Rodríguez A, Berná LM, Lozano-Carrillo C, NavarroRódenas A (2017) Basic and applied research for desert truffle 
cultivation. In: Varma A, Prasad R, Tuteja N (eds) Mycorrhiza - EcoPhysiology, Secondary Metabolites, Nanomaterials. Springer International Publishing, Cham, pp 23-42. https://doi.org/10.1007/ 978-3-319-57849-1_2

Navarro-Ródenas A, Bárzana G, Nicolás E, Carra A, Schubert A, Morte A (2013) Expression analysis of aquaporins from desert truffle mycorrhizal symbiosis reveals a fine-tuned regulation under drought. Mol Plant-Microbe Interact 26(9):1068-1078. https://doi.org/10. 1094/MPMI-07-12-0178-R

Navarro-Ródenas A, Nicolas E, Morte A (2015) Effect of irrigation on desert truffle mycorrhizal plants in field. XXI Reunión de la Sociedad Española de Fisiologia Vegetal. Toledo, (Spain)

Navarro-Ródenas A, Berná LM, Lozano-Carrillo C, Andrino A, Morte A (2016) Beneficial native bacteria improve survival and mycorrhization of desert truffle mycorrhizal plants in nursery conditions. Mycorrhiza 26(7):769-779. https://doi.org/10.1007/ s00572-016-0711-6

Navarro-Ródenas A, Ruíz-Lozano JM, Kaldenhoff R, Morte A (2012) The aquaporin TcAQP1 of the desert Truffle Terfezia claveryi is a membrane pore for water and $\mathrm{CO}_{2}$ transport. Mol Plant-Microbe Interact 25(2):259-266. https://doi.org/10.1094/MPMI-07-11-0190

Olivier JPM, Savignac JC, Sourzat P (2012) Truffe et trufficulture. FANLAC Editions, Périgueux, France
Pacioni G, Leonardi M, Di Carlo P, Ranalli D, Zinni A, De Laurentiis G (2014) Instrumental monitoring of the birth and development of truffles in a Tuber melanosporum orchard. Mycorrhiza 24(1):6572. https://doi.org/10.1007/s00572-014-0561-z

Scheffer F (2002) Lehrbuch der Bodenkunde, Scheffer, Schachtschabel, 5 th edn. Spektrum Akademischer Verlag, Heidelberg

Teramoto M, Wu B, Hogetsu T (2012) Transfer of ${ }^{14} \mathrm{C}$-photosynthate to the sporocarp of an ectomycorrhizal fungus Laccaria amethystina. Mycorrhiza 22(3):219-225

Volpato G, Rossi D, Dentoni D (2013) A reward for patience and suffering: Ethnomycology and commodification of desert truffles among Sahrawi refugees and nomads of Western Sahara. Econ Bot 67(2): $147-160$

Xu H, Navarro-Ródenas A, Cooke JEK, Zwiazek JJ (2016) Transcript profiling of aquaporins during basidiocarp development in Laccaria bicolor ectomycorrhizal with Picea glauca. Mycorrhiza 26(1):19 31. https://doi.org/10.1007/s00572-015-0643-6

Publisher's note Springer Nature remains neutral with regard to jurisdictional claims in published maps and institutional affiliations. 